\title{
Good practices for preventing ventilator-associated pneumonia in the emergency department
}

\author{
Boas práticas para prevenção de pneumonia associada à \\ ventilação mecânica no serviço de emergência \\ Buenas prácticas para prevención de neumonía asociada con la \\ ventilación mecánica en el servicio de urgencias
}

How to cite this article:

Frota ML, Campanharo CRV, Lopes MCBT, Piacezzi LHV, Okuno MFP, Batista REA. Good practices for preventing ventilator-associated pneumonia in the emergency department. Rev Esc Enferm USP. 2019;53:e0460. DOI: http://dx.doi.org/10.1590/S1980-220X2018010803460

\section{Melissa Lopes Frota ${ }^{1}$ \\ Cássia Regina Vancini Campanharo ${ }^{1}$ \\ Maria Carolina Barbosa Teixeira Lopes ${ }^{1}$ \\ Luiz Humberto Vieri Piacezzi ${ }^{1}$ \\ Meiry Fernanda Pinto Okuno ${ }^{1}$ \\ Ruth Ester Assayag Batista ${ }^{1}$ \\ ${ }^{1}$ Universidade Federal de São Paulo, Escola Paulista de Enfermagem, São Paulo, SP, Brazil.}

\begin{abstract}
Objective: To evaluate the conformity of the set of good practices for preventing ventilator-associated pneumonia (VAP) in the emergency department of a university hospital. Method: A cross-sectional analytical study with a quantitative approach, conducted in a university hospital in the city of São Paulo. The study sample consisted of opportunities for care observations that comprise the set of good practices for preventing ventilator-associated pneumonia provided to intubated patients hospitalized in the emergency department. Results: A total of 209 observations were performed in 42 patients. Of the hospitalized patients, $23.8 \%$ developed VAP, and $52.4 \%$ died. Of the five recommended measures for preventing VAP, only two presented compliance above $50 \%$. Conclusion: The care provided to patients is not in line with what is recommended in the literature, which demonstrates the need for periodic renewal of the team's educational practices and the development of auditing projects to ensure improvements in the care process.
\end{abstract}

\section{DESCRIPTORS}

Emergency Nursing; Respiration, Artificial; Pneumonia, Ventilator-Associated; Patient Care Bundles; Quality Improvement. 


\section{INTRODUCTION}

The purpose of Emergency Services (ES) is to treat patients with acute health problems as early as possible, whereas it is necessary to ensure stabilization of these critical patients ${ }^{(1)}$. Many require intensive care, but with increasing demand for ES resulting from a higher prevalence of chronic diseases, accidents and urban violence, these services are subject to overcrowding ${ }^{(2)}$. Added to this situation of immediate unavailability of vacancies are critical patients who stay longer in the emergency department requiring intensive care ${ }^{(2)}$. These include the use of invasive ventilator support, which requires specialized care from the multiprofessional team.

Patients on invasive mechanical ventilation may develop Ventilator-Associated Pneumonia (VAP), which arises when there is bacterial invasion of the lung parenchyma in patients submitted to intubation and mechanical ventilation for more than 48 hours $^{(3-4)}$, being related to secretion aspiration, colonization of the aerodigestive tract, and/or use of contaminated equipment or medications ${ }^{(3-4)}$. VAP can be classified as precocious when it occurs until the fourth day of intubation, or late when it occurs after this period ${ }^{(5)}$.

A reduction of the body's primary defenses, increased risk of airway contamination and the presence of multi-resistant microorganisms in the environment are the risk factors for developing $\operatorname{VAP}^{(6)}$, as well as the use of broad spectrum antimicrobials as empirical treatment and extended usage time of a mechanical ventilator ${ }^{(5,7)}$.

Epidemiological data on VAP show that morbidity and mortality are high ${ }^{(6-7)}$, as overall mortality ranges from $20 \%$ to $60 \%^{(7)}$. In the United States, 5 to 10 episodes of healthcare-related pneumonia occur in every 1000 admissions per year, with about two cases per 1,000 days of ventilator use ${ }^{(6)}$. In Brazil, it is estimated that more than $90 \%$ of hospitalacquired infections (HAI) correspond to pneumonia in intubated patients ${ }^{(7)}$, and the highest risk is in the first week, with an increase of $3 \%$ per day in the chances of infection ${ }^{(4,6)}$. Data from the state of São Paulo in the year 2015 indicate that the median VAP incidence was 9.87 cases per 1,000 days of ventilator use, being different in the Intensive Care Units (ICU) of teaching hospitals and private hospitals ${ }^{(7)}$.

In addition to high morbidity and mortality, this complication results in an increase in length of hospital stay and $\operatorname{costs}^{(3,7)}$. Patients with VAP can remain hospitalized, with an increase of 12 days in the hospitalization period, and hospital costs may exceed $\$ 40,000$ USD per episode ${ }^{(6-7)}$.

As a worldwide problem, the Institute for Healthcare Improvement (IHI) created in 2003 a set of measures to prevent VAP occurrence, which became known as the VAP bundle, and was last updated in the year 2012, with all the recommendations being strong to moderate ${ }^{(7)}$. There was a sharp decrease in the incidence of this event after implementing these measures in several hospitals ${ }^{(7-9)}$.

The five measures consist of $30^{\circ}$ to $45^{\circ}$ head elevation, daily interruption of sedation, peptic ulcer prophylaxis, deep vein thrombosis (DVT) prophylaxis and oral hygiene with chlorhexidine ${ }^{(10)}$. In Brazil, the routine aspiration of subglottic secretion and measuring cuff pressure are also recommended in addition to the aforementioned measures, according to the National Health Surveillance Agency ${ }^{(7)}$.

Many hospitals develop protocols and guidelines which aim to standardize and facilitate decisions at the time of care in order to facilitate health care and ensure patient safety, including factors considered in assessing the care quality of certain health services ${ }^{(11)}$.

The protocols are developed instructions which can facilitate dissemination of effective practices and reduce errors, and may differ from each other as to the format and method of development, however they must always be based on scientific evidence ${ }^{(12)}$.

The great challenge is their implementation, since these protocols seek to modify the behavior of health professionals. However, there may be dissemination of good practices ${ }^{(11)}$ by adopting the correct techniques through a participatory approach by all the professionals of the interprofessional health team.

Although VAP is frequently diagnosed in the Intensive Care Unit, the risk of its occurrence begins at the time of intubation, which may occur in the emergency room or even in prehospital care ${ }^{(12)}$, thus demonstrating the need to adopt good practices in providing care to these patients throughout the care process, starting at the emergency or pre-hospital service.

In recognizing the impact of VAP on morbidity and mortality, length of hospital stay and costs, this study is justified due to the contribution to improving the care process and encouraging the application of good practices in order to reduce this event.

Therefore, the present study aims to evaluate the compliance of the set of good practices for preventing VAP in the emergency department of a university hospital.

\section{METHOD}

\section{STUdY TYPE}

This is a cross-sectional analytical study with a quantitative approach carried out at the emergency department of the São Paulo Hospital (HSP - Hospital São Paulo).

\section{STUdY SITE}

The study scenario was the HSP, which is the teaching hospital of the Universidade Federal de São Paulo and provides high complexity public service to an area that attends more than five million people, in addition to the demands of other cities and states. The Emergency department is divided into emergency care, the emergency room and long-stay units, which include the Intensive Care Unit, Semi-intensive Care Unit and Hospitalization Unit ${ }^{(13) .}$

\section{Population}

The study population consisted of all patients hospitalized in the Emergency department who were over 18 years of age and who were on mechanical ventilation during the period of data collection. The exclusion criteria were patients presenting incomplete information in the medical records. 


\section{Data collection}

The data collection stage was carried out from May to August 2017, in which the researcher attended the emergency department on a daily basis during all work shifts. Observation of the set of good practices for preventing VAP was confidential, in addition to obtaining data through medical records, medical and nursing prescription.

The care practices which were evaluated for compliance with good practices for VAP prevention were: correct bedhead angle (from $30^{\circ}$ to $45^{\circ}$ ), which was confirmed with a goniometer; performing daily awakening, with interruption or reduced infusion of sedatives in 24 hours; prescription and proper administration of gastric protectors for patients presenting a history of peptic ulcer (omeprazole, ranitidine or any other antacid medication); implementing prophylactic measures for deep venous thrombosis (anticoagulant drugs such as heparin, enoxaparin or others, or non-medicated high compression stockings or pneumatic compressors); and oral hygiene with chlorhexidine $0.12 \%$ in intubated patients three to four times a day ${ }^{(10)}$.

The observations related to the bed elevation were divided according to the resource used (beds or stretchers), with the latter only being used in the emergency room.

The diagnostic criteria for defining VAP were radiological image worsening, temperature alteration, white blood cell (WBC) count, gas exchange worsening $\left(\mathrm{PaO}_{2} / \mathrm{FiO}_{2}\right.$ ratio $)$ or worsening of the tracheal secretion aspect ${ }^{(7)}$.

Data analysis and processing

The variables for the data analysis and processing were entered into Microsoft Office Excel 2016 spreadsheets. Mean, standard deviation, median, minimum and maximum were calculated for the continuous variables, while frequency and percentage were calculated for categorical variables. The association between the variables age and VAP development was performed using the t-test, while the hospitalization and mechanical ventilation time with VAP development was performed by the Mann-Whitney test. Fisher's Exact Test was used for the association of the prevention control measures of VAP development, and the Likelihood Ratio test was used to verify which sector was more adequate to the measures of good practices for VAP prevention. A significance level of $5 \%$ ( $p$-value $<0.05$ ) was considered.

\section{ETHICAL ASPECTS}

This study was approved by the Research Ethics Committee of Universidade Federal de São Paulo (UNIFESP), according to the Opinion no. 2.014.904, in the year 2017. The study met the ethical precepts of research involving human beings, since it was conducted according to the recommendations of Good Clinical Practices and Resolution No. 466 of 2012 of the National Health Council/ Ministry of Health.

\section{RESULTS}

There were 209 observations made in total, including 42 patients, $50.0 \%$ male, with a mean age of 65.5 years (SD 16.9). Of the total number of observations, 49 (23.4\%) were made in the morning, 53 (25.4\%) in the afternoon and 107 (51.2\%) in the night period; 25 (12.0\%) were performed in the Emergency Room, 151 (72.2\%) in the Emergency Room ICU, 25 (12.0\%) in the Semi-Intensive Unit, and 8 (3.8\%) in the Emergency Hospitalization Unit.

Table 1 - Clinical variables of patients with artificial airways admitted to the Emergency Department - São Paulo, SP, Brazil, 2017.

\begin{tabular}{lc}
\hline Clinical variables & Total (\%) \\
\hline Ventilation time & \\
Mean (SD) & $14.6(14.8)$ \\
\hline Hospitalization causes & \\
Pulmonary & $11(26.2)$ \\
Neurological & $10(23.8)$ \\
Infection & $6(14.3)$ \\
Others & $6(14.3)$ \\
Cardiovascular & $5(11.9)$ \\
Gastrointestinal & $4(9.5)$ \\
\hline
\end{tabular}

*SD: standard deviation.

Note: $(n=42)$

The mean hospital stay $(n=42)$ was 25.3 days, one patient remained hospitalized after the end of the data collection period. The main causes of hospitalization were pulmonary afflictions (26.2\%), followed by neurological causes (23.8\%) (Table 1). Of the total number of patients, $23.8 \%$ developed VAP during hospitalization, and $52.4 \%$ evolved to death.

Of the observations, $157(75.1 \%)$ were performed in patients with orotracheal tube and $52(24.9 \%)$ in patients with tracheostomy.

The conformity of good practice measures performed on patients for VAP prevention is shown in Table 2.

Table 2 - Performance frequency of good practice measures for VAP prevention in patients with artificial airways admitted to the Emergency Department - São Paulo, SP, Brazil, 2017.

\begin{tabular}{lc}
\hline Good practice measures & $\begin{array}{c}\text { Performance } \\
\text { frequency }(\%)\end{array}$ \\
\hline Bed elevation of head in degrees $(\mathrm{n}=199)$ & $85(42.8)$ \\
Stretcher elevation of head in degrees $(\mathrm{n}=10)$ & $07(70.0)$ \\
Daily interruption of sedation $(\mathrm{n}=126)$ & $65(51.6)$ \\
Peptic ulcer prophylaxis $(\mathrm{n}=209)$ & $178(85.2)$ \\
Prophylaxis for DVT* $(\mathrm{n}=209)$ & $143(68.4)$ \\
Oral hygiene performed $(\mathrm{n}=209)$ & $101(48.2)$ \\
\hline
\end{tabular}

*VAP: Ventilator-associated pneumonia; DVT: deep vein thrombosis. Note: $(n=42)$

The most performed measure was peptic ulcer prophylaxis, and those performed less frequently were head elevation and oral hygiene. Some of the inpatients were not using sedatives during the observations, which is why there is a difference in $\mathrm{N}$.

Table 3 shows the associations between age, time of hospitalization and mechanical ventilation and VAP development. Patients who developed VAP had longer hospital stay $(\mathrm{p}=0.0178)$ and mechanical ventilation $(\mathrm{p}=0.0014)$ than those who did not. 
Table 4 presents the association between control measures of VAP prevention and its development. There was no statistically significant association in the population of this study between the performance of the prevention measures and VAP development.
When comparing the hospitalization location of the patient with adherence to the control measures of VAP prevention, it was identified that the percentage of peptic ulcer prophylaxis $(\mathrm{p}=0.0016)$ and the DVT prophylaxis $(\mathrm{p}=$ 0.0001 ) were higher in the ICU than in the Emergency Room.

Table 3 - Association between age, time of hospital stay and mechanical ventilation and VAP development - São Paulo, SP, Brazil, 2017.

\begin{tabular}{|c|c|c|c|c|}
\hline & \multicolumn{2}{|c|}{ VAP* developed during hospitalization } & \multirow{3}{*}{ Total } & \multirow{3}{*}{ p-value } \\
\hline & Yes & No & & \\
\hline & n (\%) & n (\%) & & \\
\hline \multicolumn{5}{|l|}{ Age } \\
\hline Mean $\left(\mathrm{SD}^{* *}\right)$ & $66.4(20.6)$ & $65.2(16.0)$ & $65.5(16.9)$ & 0.8497 \\
\hline \multicolumn{5}{|c|}{ Hospitalization time in days $(n=41)$} \\
\hline Mean (SD) & $38.7(21.6)$ & $21(18.7)$ & $25.3(20.6)$ & 0.0178 \\
\hline Median (Min. ${ }^{\S}-$ Max..$\left.^{\S \S}\right)$ & $30(15-84)$ & $18(0-69)$ & $23(0-84)$ & \\
\hline \multicolumn{5}{|l|}{ Ventilator time in days } \\
\hline Mean $\left(\mathrm{SD}^{* *}\right)$ & $27.1(15.8)$ & $10.7(12.3)$ & $14.6(14.8)$ & 0.0014 \\
\hline Median (Min. ${ }^{\S}-$ Max. ${ }^{\S \S}$ ) & $23(11-56)$ & $5.5(0-45)$ & $11(0-56)$ & \\
\hline
\end{tabular}

*VAP: Ventilator-associated pneumonia. ${ }^{* *}$ SD: standard deviation. ${ }^{\S}$ Min.: Minimum. ${ }^{\S}$ Max.: Maximum.

Note: $(n=42)$.

Table 4 - Association of implementing good practice measures and VAP development - São Paulo, SP, Brazil, 2017.

\begin{tabular}{|c|c|c|c|c|}
\hline \multirow{3}{*}{ Good practice measures } & \multicolumn{2}{|c|}{ VAP* development during hospitalization } & \multirow{3}{*}{ Total } & \multirow{3}{*}{ p-value } \\
\hline & Yes & No & & \\
\hline & n (\%) & n (\%) & & \\
\hline \multicolumn{5}{|c|}{ Head elevation in degrees (bed) } \\
\hline Yes & $8(32.0)$ & $17(68.0)$ & $25(100)$ & 0.2786 \\
\hline No & $2(14.3)$ & $12(85.7)$ & $14(100)$ & \\
\hline Patient total & $10(25.6)$ & $29(74.4)$ & $39(100)$ & \\
\hline \multicolumn{5}{|c|}{ Head elevation in degrees (stretcher) } \\
\hline Yes & - & $3(100)$ & $3(100)$ & - \\
\hline No & - & - & - & \\
\hline Patient total & - & $3(100)$ & $3(100)$ & \\
\hline \multicolumn{5}{|c|}{ Daily interruption of sedation } \\
\hline Yes & $7(30.4)$ & $16(69.6)$ & $23(100)$ & 0.0695 \\
\hline No & - & $12(100.0)$ & $12(100)$ & \\
\hline Patient total & $7(20.0)$ & $28(80.0)$ & $35(100)$ & \\
\hline \multicolumn{5}{|l|}{ Peptic ulcer prophylaxis } \\
\hline Yes & $9(25.7)$ & $26(74.3)$ & $35(100)$ & 1.0000 \\
\hline No & $1(14.3)$ & $6(85.7)$ & $7(100)$ & \\
\hline Patient total & $10(23.8)$ & $32(76.2)$ & $42(100)$ & \\
\hline \multicolumn{5}{|l|}{ DVT** prophylaxis } \\
\hline Yes & $9(29.0)$ & $22(71.0)$ & $31(100)$ & 0.2451 \\
\hline No & $1(9.1)$ & $10(90.9)$ & $11(100)$ & \\
\hline Patient total & $10(23.8)$ & $32(76.2)$ & $42(100)$ & \\
\hline \multicolumn{5}{|l|}{ Oral hygiene performance } \\
\hline Yes & $9(28.1)$ & $23(71.9)$ & $32(100)$ & 0.4038 \\
\hline No & $1(10.0)$ & $9(90.0)$ & $10(100)$ & \\
\hline Patient total & $10(23.8)$ & $32(76.2)$ & $42(100)$ & \\
\hline
\end{tabular}

*VAP: Ventilator-associated pneumonia; ** DVT: Deep Vein Thrombosis. 


\section{DISCUSSION}

VAP significantly impacts patient survival and causes up to $\$ 40,000$ USD in health care costs per episode, which shows the importance of implementing preventive measures ${ }^{(7)}$.

The mean age of the patients in this study was 65.5 years, the hospitalization time was 25.3 days and the mechanical ventilation time was 14.6 days; similar data to those found in the national literature. In two studies performed in the sectors of Adult and Emergency Care Units, one conducted in Minas Gerais $(\mathrm{n}=190)$ and another in Santa Catarina $(n=120)$, the mean age was between 56.9 and 58.6 years and hospitalization time was between 9.5 and 15.2 days, respectively. In addition, the mean mechanical ventilation time in these sites was between 13.1 and 17.4 days ${ }^{(14-15)}$. Furthermore, in two other international studies, one conducted in Saudi Arabia $(\mathrm{n}=3,665)$ and another in the United States $(n=5,539)$, the mean age was between 56.4 and 61.2 years, and the hospitalization time was 25 days ${ }^{(16-17)}$. However, there was a difference in mean mechanical ventilation time, which was 6.9 and 8.8 days ${ }^{(16-17)}$.

The mean older age, as well as the longer mechanical ventilation and hospitalization times can be justified by the reduction in the body's defenses, as well as greater exposure to risk factors and chronic diseases ${ }^{(18)}$. The shorter mechanical ventilation time in international hospitals may be related to more effective application of VAP prevention measures and greater access to technology.

The VAP prevalence in this study was $23.8 \%$. This finding corroborates national studies in which the VAP prevalence was $23.2 \%{ }^{(14)}$ and $31.8 \%{ }^{(15)}$. International studies have shown that VAP incidence varies from $8.0 \%$ to $25.0 \%$, reaching $31.0 \%$ in the United States ${ }^{(19-20)}$. The difference in these findings can be attributed to the diagnostic criteria for VAP, which may under or overestimate this condition ${ }^{(21)}$.

This study presented $52.4 \%$ mortality, being a similar rate to that found in the national literature $(60.0 \%)^{(7,22)}$ and high compared to the international literature $(35.0 \%)^{(20)}$. The high number of deaths in Brazil may indicate the need for improvements in care processes and in training the interprofessional team that acts in the provided care ${ }^{(23)}$.

In this study, head elevation was observed $42.8 \%$ of the time. Compliance with this recommendation in the literature ranged from $37.7 \%$ in national studies ${ }^{(22,24)}$ to $99.0 \%^{(20)}$ in international studies. In general, these studies aimed to identify VAP incidence, to verify that the prevention measures were properly carried out, to assess their compliance and to investigate the impact of implementing the VAP bundle on the occurrence rates ${ }^{(20,22,24)}$, so that the designs were similar to that of this study. The variation in these findings can be explained by cultural diversity, as well as by the level of socioeconomic development, which can result in differences in hospital infrastructure and human and material resources, thus increasing adherence to protocols.

Daily interruption of sedation was performed in $51.6 \%$ of the observations in this study. A national study which evaluated the performance of measures to prevent VAP and its incidence performed in the state of Bahia, showed that daily discontinuation of sedation was performed $100 \%$ of the time and a shorter mean mechanical ventilation time of 5.9 days ${ }^{(22)}$. A study carried out in 10 institutions in Taiwan which evaluated the impact of the bundle implementation on VAP rates, showed that this measure was performed in $93.0 \%$ or more in the observations ${ }^{(20)}$. At this point, it is important to emphasize that the use of an institutional protocol that can standardize the actions for the correct performance of daily wakening and the weaning of sedation is recommended in order to guarantee patient safety ${ }^{(25)}$.

Peptic ulcer prophylaxis was the most performed measure in this study in $85.2 \%$ of the observations. Studies have found the non-use ${ }^{(24)}$ and adhesions to this measure between $56.0 \%{ }^{(19)}$ and $100 \%{ }^{(22)}$. This measure can be challenged in practice, since the risks and benefits of its application to the patient should be weighed. The use of proton pump inhibitors alters the gastric juice $\mathrm{pH}$, changing the colonization pattern of several pathogens, and may even increase the risk of VAP, but gastrointestinal bleeding is a common complication in critically ill patients ${ }^{(26)}$.

DVT prophylaxis was performed in $68.4 \%$ of the observations in this study. Studies with the objective of identifying the performance of this measure for VAP prophylaxis are still scarce, considering that this care is not directly related to VAP occurrence, but to the prevention of thromboembolic events, including pulmonary thromboembolism ${ }^{(26)}$, which may worsen the patient's clinical condition and prolong the mechanical ventilation time.

Oral hygiene performance was observed in $48.2 \%$ of the time in this study. The national literature demonstrates compliance of this measure between $84.7 \%^{(24)}$ and $100.0 \%^{(22)}$, while in an international study the average was $99 \%{ }^{(20)}$. This means that the frequency of oral hygiene performance in the present study was well below expectations, which can be justified by the recurrent unavailability of the material needed for its execution in the health service and the absence of supervising the performance of this measure.

Two other interventions recommended as routine practices, although not included in the VAP prevention bundle, are subglottic aspiration and cuff pressure monitoring ${ }^{(20,22,24)}$. These care procedures were not included in the observations of this study due to the unavailability of material needed for its performance in the research institution.

Regarding the observed units, there was greater adherence to bundle measures for VAP prevention in the ICU compared to the Emergency Room and the Emergency Department Hospitalization Unit. This may be related to the fact that the ICU is characterized as a sector that receives critical patients and requires high complexity care for an extended period of time, which is not the case with other sites $^{(27)}$. However, the reality of most institutions with the profile of this site under study is the Emergency Service which meets the spontaneous demand of users, combined with a lack of intensive care beds in the Unified Health System, which causes these critical patients to remain hospitalized in the Emergency sector, thereby causing overcrowding in these services, overloading the team, and consequently decreasing the safety and quality of care provided ${ }^{(2)}$. 
Another factor to be considered is the heterogeneity among team members regarding the difference in training and daily experiences, which can cause differences in the way care is executed and hinder adherence to new practices ${ }^{(28)}$. For this reason, the continuing education of the interprofessional team does not only act in educational processes and care quality, but also in supervising the care and management of the units, thus ensuring that new norms are incorporated into clinical practice, enabling a decrease in the occurrence of adverse events such as $\operatorname{VAP}^{(23,29)}$.

The main limitation of this study was the fact that it was performed in a single center, and because it is a school hospital, the patients remain hospitalized for long periods, with a consequent decrease in turnover. Another limiting factor was the incompleteness of medical records, which resulted in excluding some patients.

The importance of the contribution of this research is emphasized in recognizing the need to improve compliance to the set of good practices and the lack of national studies to identify failures in VAP prevention in the context of Emergency Services, with the objective of improving care practices, patient safety and outcomes.

\section{CONCLUSION}

In evaluating the compliance of the set of good practices for VAP prevention in the Emergency Department, this study concluded that head elevation and oral hygiene presented less than $50 \%$ compliance among the five measures, while daily interruption of sedation and DVT prophylaxis showed between $50 \%$ and $70 \%$ compliance, and peptic ulcer prophylaxis presented greater than $80 \%$ compliance. These results show the negative impact that insufficient material and human resources in addition to patient overcrowding in intensive care in the emergency department can have on care quality, since they require a highly specialized environment and team. These factors also hinder practice based on international recommendations and scientific evidence, reinforce the need for improvements in public health services, the need for constant improvements in the care process, as well as periodic renewal of educational practices of the interprofessional team and to develop assessment projects to effectively reduce VAP incidence and improve patient safety by promoting care quality.

\section{RESUMO}

Objetivo: Avaliar a conformidade do conjunto de boas práticas para prevenção da pneumonia associada à ventilação mecânica no serviço de urgência e emergência de um hospital universitário. Método: Estudo transversal, analítico e de abordagem quantitativa, realizado em um hospital universitário na cidade de São Paulo. A amostra do estudo foi composta de oportunidades de observações dos cuidados que compõem o conjunto de boas práticas para prevenção da pneumonia associada à ventilação mecânica, prestados aos pacientes intubados internados no serviço de Urgência e Emergência. Resultados: Foram realizadas 209 observações em 42 pacientes. Dos pacientes internados, $23,8 \%$ desenvolveram pneumonia associada à ventilação mecânica, e 52,4\% foram a óbito. Das cinco medidas preconizadas para a prevenção de pneumonia associada à ventilação mecânica, apenas duas apresentaram conformidade acima de $50 \%$. Conclusão: Os cuidados prestados aos pacientes não estão em conformidade com o recomendado na literatura, o que demonstra a necessidade de renovação periódica das práticas educativas da equipe e o desenvolvimento de projetos de auditoria para assegurar melhorias no processo assistencial.

\section{DESCRITORES}

Enfermagem em Emergência; Respiração Artificial; Pneumonia Associada à Ventilação Mecânica; Pacotes de Assistência ao Paciente; Melhoria de Qualidade.

\section{RESUMEN}

Objetivo: Evaluar la conformidad del conjunto de buenas prácticas para prevención de neumonía asociada con la ventilación mecánica en el servicio de urgencias y emergencia de un hospital universitario. Método: Estudio transversal, analítico y de abordaje cuantitativo, realizado en un hospital universitario de São Paulo. La muestra del estudio estuvo compuesta de oportunidades de observaciones de los cuidados que componen el conjunto de buenas prácticas para la prevención de la neumonía asociada con la ventilación mecánica, prestados a los pacientes intubados hospitalizados en el servicio de Urgencias y Emergencia. Resultados: Se llevaron a cabo 209 observaciones en 42 pacientes. De los pacientes hospitalizados, el 23,8\% desarrollaron neumonía asociada con la ventilación mecánica, y el $52,4 \%$ fallecieron. De las cinco medidas preconizadas para la prevención de neumonía asociada con la ventilación mecánica, solo dos presentaron conformidad por encima del 50\%. Conclusión: Los cuidados prestados a los pacientes no están en conformidad con lo recomendado en la literatura, lo que demuestra la necesidad de renovación periódica de las prácticas educativas del equipo y el desarrollo de proyectos de auditoría para asegurar mejorías en el proceso asistencial.

\section{DESCRIPTORES}

Enfermería de Urgencia; Respiración Artificial; Neumonía Asociada al Ventilador; Paquetes de Atención al Paciente; Mejoramiento de la Calidad.

\section{REFERENCES}

1. Brasil. Ministério da Saúde. Portaria n. 1600, de 7 de julho de 2001. Reformula a Política Nacional de Atenção às Urgências e institui a Rede de Atenção às Urgências no Sistema Único de Saúde (SUS) [Internet]. Brasília; 2001 [citado 2018 mar. 23]. Disponível em: http:// bvsms.saude.gov.br/bvs/saudelegis/gm/2011/prt1600_07_07_2011.html

2. Paixão TCR, Campanharo CRV, Lopes MCBT, Okuno MFP, Batista REA. Nursing staff sizing in the emergency room of a university hospital. Rev Esc Enferm USP [Internet]. 2015 [cited 2018 Mar 23];49(3):486-93. Available from: http://www.scielo.br/scielo.php?script=sci_ arttext\&pid=S0080-62342015000300481\&lng=en\&nrm=iso\&tlng=en 
3. Associação Paulista de Epidemiologia e Controle de Infecção Relacionada à Assistência à Saúde. Um compêndio de estratégias para a prevenção de infecções relacionadas à assistência à saúde em hospitais de cuidados agudos [Internet]. São Paulo: APECIH; 2008[citado 2018 mar. 23]. Disponível em: http://www.apecih.org.br/upload/downloads/APECIH-Compendio-Estrategias-de-Prevencao-de-Infeccao.pdf

4. Silva RM, Silvestre MO, Zocche TL, Sakae TM. Pneumonia associada à ventilação mecânica: fatores de risco. Rev Bras Clin Med. 2011;9(1):5-10.

5. Sociedade Brasileira de Pneumologia e Tisiologia. Diretrizes brasileiras para tratamento das pneumonias adquiridas no hospital e das associadas à ventilação mecânica. J Bras Pneumol [Internet]. 2007 [citado 2018 mar. 23];33 Supl 1:S1-30. Disponível em: http://www. ccih.med.br/suple_131_44_1diretrizes1.pdf

6. Marini AL, Khan R, Mundekkadan S. Multifaceted bundle interventions shown effective in reducing VAP rates in our multidisciplinary ICUs. BMJ Qual Improv Rep. 2016;5(1):pii: u205566.w2278. DOI: http://dx.doi.org/10.1136/bmjquality.u205566.w2278

7. Brasil. Mistério da Saúde; Agência Nacional de Vigilância Sanitária. Medidas de Prevenção de Infecção Relacionada à Assistência à Saúde. Brasília: ANVISA; 2017.

8. Souza AF, Guimarães AC, Ferreira EF. Avaliação da implementação de novo protocolo de higiene bucal em um centro de terapia intensiva para prevenção de pneumonia associada à ventilação mecânica. Rev Min Enferm [Internet]. 2013 [citado 2018 mar. 23];17(1):177-184. Disponível em: http://www.reme.org.br/artigo/detalhes/588

9. Al-Thaqafy MS, El-Saed A, Arabi YM, Balkhy HH. Association of compliance of ventilator bundle with incidence of ventilator-associated pneumonia and ventilator utilization among critical patients over 4 years. Ann Thorac Med [Internet]. 2014 [cited 2018 mar. 23];9(4):221-6. Available from: https://www.ncbi.nlm.nih.gov/pmc/articles/PMC4166069/

10. Institute for Healthcare Improvement. How-to guide: prevent ventilator-associated pneumonia [Internet]. Cambridge, MA; 2012 [cited 2018 Mar 23]. Available from: http://www.chpso.org/sites/main/files/file-attachments/ihi_howtoguidepreventvap.pdf

11. Brasil. Ministério da Saúde; Agência Nacional de Vigilância Sanitária. Assistência segura: uma reflexão teórica aplicada à prática [Internet] Brasília: ANVISA; 2013 [citado 2018 mar. 23]. Disponível em: http://www20.anvisa.gov.br/segurancadopaciente/images/documentos/ livros/Livro1-Assistencia_Segura.pdf

12. DeLuca LA Jr, Walsh P, Davison DD Jr, Stoneking LR, Yang LM, Grall KJ, et al. Impact and feasibility of an emergency department-based ventilator associated pneumonia bundle for patients intubated in an academic emergency department. Am J Infec Control. 2017;45(2):151-7. DOI: http://www.dx.doi.org/10.1016/j.ajic.2016.05.037.

13. Universidade Federal de São Paulo; Hospital São Paulo. Atendimento Hospitalar [Internet]. São Paulo; 2018 [citado 2018 mar. 23 ]. Disponível em: http://www.hospitalsaopaulo.org.br/atendimento-hospitalar

14. Mota EC, Oliveira SP, Silveira BRM, Silva PLN, Oliveira AC. Incidência da pneumonia associada à ventilação mecânica em unidade de terapia intensiva. Medicina (Ribeirão Preto) [Internet]. 2017 [citado 2018 mar. 23];50(1):39-46. Disponível em: http://www.revistas.usp. $\mathrm{br} / \mathrm{rmrp} / \mathrm{article} / \mathrm{view} / 135044$

15. Kock KS, Rosa BC, Martignago N, Maurici R. Pneumonia associada à Ventilação Mecânica (PAVM): incidência e desfecho clínico em uma unidade de terapia intensiva no Sul de Santa Catarina. Arq Catarin Med [Internet]. 2017 [citado 2018 mar. 23]; 46(1):02-11. Disponível em: http://www.acm.org.br/acm/seer/index.php/arquivos/article/view/248/135

16. Khan R, Al-Dorzi HM, Al-Attas K, Ahmed FW, Marini AM, Mundekkadan S, et al. The impact of implementing multifaceted interventions on the prevention of ventilator-associated pneumonia. Am J Infect Control. 2016;44(3):320-6. DOI: http://dx.doi.org/10.1016/j. ajic.2015.09.025

17. Klompas M, Lingling L, Kelinman K, Szumita PM, Massaro AF. Associations between ventilator bundle components and outcomes. JAMA Intern Med. 2016;176(9):1277-83. DOI: http://www.dx.doi.org/10.1001jamainternmed.2016.2427.

18. Charles MVP, Kali A, Easow JM, Joseph NM, Ravishankar M, Srinivasan S, et al. Ventilator-associated pneumonia. Austr Med J. 2014;7(8):33444. DOI: http://www.dx.doi.org/10.4066/AMJ.2004.2015

19. Saied WI, Souwiene B, Orgeas MG, Ruckly S, Darmon M, Bailly S, et al. Respective impact of implementation of prevention strategies, colonization with multiresistant bacteria and antimicrobial use on the risk of early- and late-onset VAP: an analysis of the OUTCOMEREA network. PLoS One [Internet]. 2017 [cited 2018 Mar 23];12(11):e0187791. Available from: https://www.ncbi.nlm.nih.gov/pmc/articles/ PMC5706682/

20. Kao CC, Chiang HT, Chen CY, Hung CT, Chen YC, Su LH, et al. National bundle care program implementation to reduce ventilatorassociated pneumonia in intensive care units in Taiwan. J Microbiol Immunol Infect. 2017; pii:S1684-1182(17)30237-2. DOI: http://dx.doi. org/10.1016/j.jmii.2017.11.001

21. Kalil AC, Metersky ML, Klompas M, Muscedere J, Sweeney DA, Palmer LB, et al. Management of adults with hospital-acquired and ventilator-associated pneumonia: 2016. Clinical Practice Guidelines by the Infectious Diseases Society of America and the American Thoracic Society. Clin Infect Dis [Internet]. 2016 [cited 2019 Jan 14];63(5):e61-111. Available from: https://www.ncbi.nlm.nih.gov/pmc/ articles/PMC4981759/

22. Amaral JM, Ivo OP. Prevenção de pneumonia associada à ventilação mecânica: um estudo observacional. Rev Enferm Contemp [Internet]. 2016 [citado 2018 mar. 23];5(1):109-17. Disponível em: https://www5.bahiana.edu.br/index.php/enfermagem/article/view/926/654

23. Mansano FPN, Belei RA, Vinci LAS, Melo BLD, Cardoso LTQ, Garcia JCP, et al. Impacto de ação educativa na manutenção do decúbito elevado como medida preventiva de pneumonia associada à ventilação mecânica em Unidade de Terapia Intensiva. ABCS Health Sci. 2017;42(1):21-6. DOI: http://dx.doi.org/10.7322/abcshs.v42i1.945

24. Silva SG, Salles RK, Nascimento ERP, Bertoncello KCG, Cavalcanti CDK. Evaluation of a bundle to prevent ventilator-associated pneumonia in an Intensive Care Unit. Texto Contexto Enferm [Internet]. 2014 [cited 2018 Mar 23];23(3):744-50. Available from: http://www.scielo. br/pdf/tce/v23n3/0104-0707-tce-23-03-00744.pdf

25. Nassar Junior AP, Park M. Sedation protocols versus daily sedation interruption: a systematic review and meta-analisys. Rev Bras Ter Intensiva [Internet]. 2016 [cited 2018 Mar 23];28(4):444-51. Available from: http://www.scielo.br/pdf/rbti/v28n4/en_0103-507X-rbti-28-04-0444.pdf 
26. Ribeiro J, Gomes SR. A aplicabilidade do bundle na prevenção e controle de pneumonia associada à ventilação mecânica. Rev Interdisc Pensamento Cient. 2017;3(1):74-86. DOI: http://dx.doi.org/10.20951/2446-6778/v3n1a6

27. Santos FC, Camelo SH. Las enfermeras que trabajan em unidades de cuidados intensivos: perfil y formación profesional. Cultura Cuidados [Internet]. 2015 [citado 2018 mar. 23];19(43)127-40. Disponible en: https://rua.ua.es/dspace/bitstream/10045/52599/1/Cult_Cuid_43_13.pdf

28. Cardoso AKS, Campos CAL, Araújo ES, Moritz FGF, Matos MML, Manso MM, et al. Leitos de retaguarda: definições e perfil dos leitos na região metropolitana de São Paulo. São Paulo: FUNDAP; 2013.

29. Chicayban LM, Terra ELVS, Ribela JS, Barbosa PF. Bundles de prevenção de pneumonia associada à ventilação mecânica: a importância da multidisciplinaridade. Rev Perspect Biol Saúde [Internet]. 2014 [citado 2018 mar. 23];25(7)25-35. Disponível em: http://seer. perspectivasonline.com.br/index.php/biologicas_e_saude/article/view/1200/ 